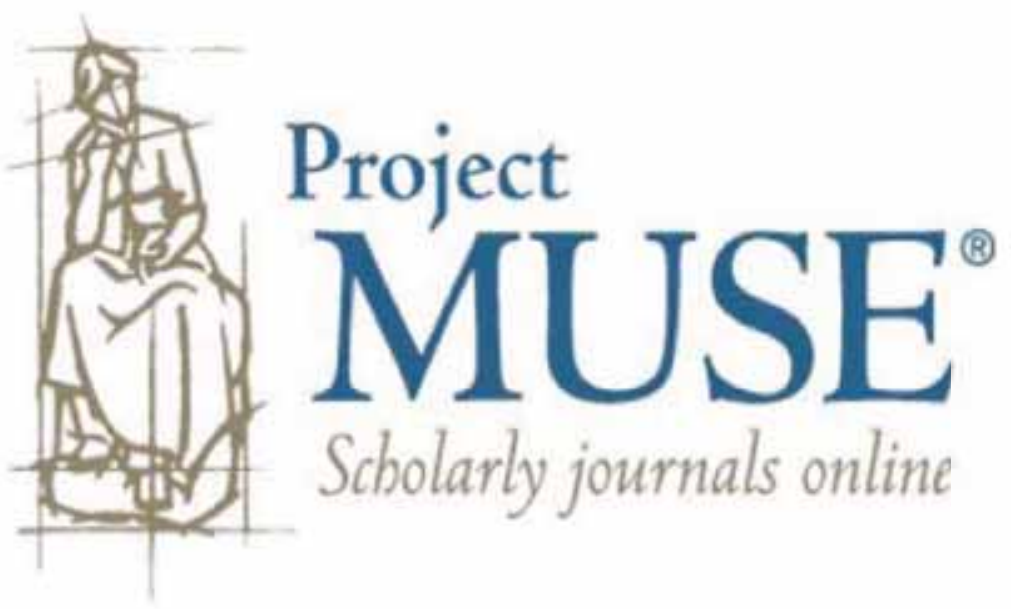




\title{
The Effects of Heavy Episodic Alcohol Use on Student Engagement, Academic Performance, and Time Use
}

\author{
Stephen R. Porter John Pryor
}

Alcohol use literature has linked heavy episodic alcohol use and academic consequences, but has not examined the influence of such use on student engagement. This study uses survey data from over 40,000 students at 28 selective private colleges and universities to examine the connection between heavy episodic alcohol use and engagement. The strongest negative effects of heavy episodic drinking are on student-faculty interaction, with these effects most common at research universities and less common at coed colleges and women's colleges.

One of the more influential models used to examine the impact of college on students has been Astin's (1984) model of student involvement; the more students are involved in college activities, the more they will gain from their college experience. Researchers have demonstrated the relationship between student engagement and gains made in college (Astin, 1993; Kuh, Schuh, Whitt \& Associates, 1991; Pascarella \& Terenzini, 1991, 2005). The degree of involvement in different aspects of college life, such as faculty-student interaction, student organizations and clubs, and student social life, impacts how much students gain from college, both inside and outside of the classroom (Kuh, Douglas, Lund, \& RaminGyurnek, 1994). Involvement with faculty has a positive effect on a multitude of college behaviors and outcomes, such as grade point average (GPA), degree attainment, academic honors, graduate and professional school admission, satisfaction with college, and selfreported gains in academic and personal growth (Astin, 1993; Kuh \& Hu, 2001). Participation in student organizations and clubs has a positive effect on leadership and satisfaction (Astin, 1993). Interactional diversity, the quality of effort that students put into interactions with those who are different from them, positively influences not only diversity-related outcomes, but most other learning outcomes of college ( $\mathrm{Hu} \& \mathrm{Kuh}$, 2002).

Levels of involvement in college life differ according to certain student characteristics and the student's college environment. For instance, first-year students are less likely to interact with faculty than seniors (Astin, 1993; Kuh \& Hu, 2001). Students at research universities are also less likely to interact with faculty than students at other types of institutions (Kuh \& $\mathrm{Hu}$ ).

Students engage in many types of activities in college-some that have positive effects and some that have negative effects. Students in fraternities or sororities tend to have higher levels of engagement in college on a variety of levels, both academic and social (Astin, 1993; Pike \& Askew, 1990). Astin (1993) also found that alcohol consumption has a positive correlation with fraternity and sorority membership and other social aspects of college and pointed out that alcohol consumption has an "unusual" impact on college outcomes in

Stephen R. Porter is Associate Professor of Educational Leadership and Policy Studies at Iowa State University. John Pryor is Managing Director of the Higher Education Research Institute at the University of California, Los Angeles. 
that "drinking is negatively related to college GPA and graduating with honors, but positively related to the attainment of the bachelor's degree" (pp. 393-394). The measure of alcohol consumption used in this research, however, was quite broad, with a student being considered a drinker if he or she reported drinking beer, liquor, or wine "occasionally" or "frequently" in the previous year (the remaining category being "never"). As many as three quarters of college students fall into this rather broad category (Astin, 1993).

\section{LITERATURE REVIEW}

One of the most problematic aspects of college-student life is alcohol use and the related negative consequences (The Carnegie Foundation for the Advancement of Teaching, 1990; National Institute on Alcohol Abuse and Alcoholism, 2002). Alcohol use in college is correlated with death, sexual assault, bodily injury, academic failure, and academic underperformance. National estimates of alcoholrelated unintentional injury deaths range from 1,600 to 1,700 per year (Hingson, Heeren, Winter \& Wechsler, 2005; Hingson, Heeren, Zakos, Kopstein \& Wechsler, 2002). In a national survey, senior-level college administrators estimated that $30 \%$ of the time alcohol was involved in student attrition (Anderson \& Gadaleto, 2001).

There is a substantial body of research indicating that many college students frequently drink alcohol at relatively high levels. The most widely used measure of alcohol consumption establishes heavy episodic drinking (also known more colloquially as "binge drinking") as having five or more drinks on one occasion at least once in the past 2 weeks (Bachman, Wadsworth, O’Malley, Johnston, \& Schulenberg, 1997; Presley, Meilman, \& Cashin, 1996). Another line of research uses a similar measure, but defines a woman who consumes only four or more drinks in the same time period as a heavy episodic drinker (Wechsler \& Nelson, 2001). Regardless of which parameter (the $5 / 5$ or $5 / 4$ ) is used, fewer students fall into the category of "heavy episodic drinkers" (approximately 45\%) than in Astin's (1993) category of "drinkers" (the aforementioned 75\%).

The alcohol use literature also examines the impact that alcohol has on the college experience. Due to their alcohol use, college students who drink at the heavy episodic level are more likely to miss class, get behind in school work, not use protection during sex, get into physical fights, and experience a wide variety of other negative consequences (Wechsler et al., 2002). They are also significantly more likely to experience blackouts (White, Jamieson-Drake, \& Swartzwelder, 2002). The impact goes beyond a personal one when one considers the second-hand effects of alcohol, such as having sleep or studying interrupted by drinkers, property damage, vomit in public spaces, and experiencing rude behavior (Wechsler et al.).

Alcohol use can impact academic progress through multiple pathways. As Powell, Williams, and Wechsler (2004) pointed out, the impairment of cognitive abilities caused by alcohol use can result in a negative influence on academic performance. In addition, the act of drinking (and the recovery from drinking) takes time away from other pursuits. Alcohol use can therefore also indirectly impact academic performance by reducing the time available for studying, attending class, and other academically related activities. Using a sample of 14,907 undergraduates who responded to the College Alcohol Survey in 1997 and 1999, Powell et al. found that among sophomore, junior, and senior students who drink alcohol, the probability of missing a class and getting behind in school due to alcohol use increased as the average number of drinks 
consumed in a week increased. The frequency of alcohol-induced blackouts is also negatively correlated with GPA (White et al., 2002).

Little is known, however, about the relationship between alcohol use by undergraduates and involvement in college. In the involvement literature, studies are limited to that by Astin (1993), using an assessment of drinking that is fairly broad, dealing only with frequency of consumption, and not able to differentiate quantities of alcohol consumed. The alcohol use literature differentiates more precise levels of consumption and contains many studies examining the direct negative impact of alcohol on health. The linkage between gains in college (and the mediating aspect of involvement) and heavy episodic alcohol use, however, has not been systematically examined beyond observations concerning GPA and variables such as missing class or missing an academic deadline (Wechsler et al., 2002).

Thus, although the benefits of involvement in college and also the negative impact of alcohol use on some academic measures can be described, an in-depth understanding of how alcohol use might impact involvement and, thus, ultimately the gains made from college is lacking. Many questions still exist. For instance, do students who consume higher amounts of alcohol engage with faculty in the same ways as students who do not consume alcohol at this level? What is the relationship between heavy episodic drinking and how much effort students put forth in academic challenges in college? How does heavy episodic drinking impact the time spent on other activities in college?

\section{METHODOLOGY}

\section{Data}

We used survey data from 41,598 undergraduate students at 28 highly selective, 4-year, private institutions to examine the connection between engagement in college and alcohol use. The survey examines issues of engagement, as do many other available instruments, but unlike these other instruments the survey also includes a question concerning heavy episodic drinking.

The survey was administered via the web in the spring of 2003, resulting in an overall response rate of $48 \%$ (institutional response rates ranged from $38 \%$ to $73 \%$ ). Although the 28 schools are similar in terms of selectivity, they differ by type of institution: research universities, coeducational liberal arts colleges, and women's colleges. Separate research has indicated that both engagement in college $(\mathrm{Hu}$ \& Kuh, 2002; Umbach \& Wawrzynski, 2004) and alcohol consumption (Powell et al., 2004; Wechsler et al., 2002; Weitzman, Nelson, \& Wechsler, 2003) differ by institutional type. Because the relationship between alcohol use and engagement may differ between these types of institutions, we analyzed their data separately. Similarly, because alcohol use and engagement may differ between females and males, we analyzed them separately. We thus had five samples in our analyses: females and males at research universities $(n=32,338)$, females and males at liberal arts colleges $(n=5,446)$, and females at women's colleges $(n=3,815)$. We also used survey weights to account for survey non-response and to standardize differential sampling procedures used at the various institutions.

\section{Dependent Variables}

We used three sets of dependent variables. The first variable, self-reported cumulative GPA (taken from a six-point interval scale-A, A-, $\mathrm{B}+, \mathrm{B}, \mathrm{B}-/ \mathrm{C}+, \mathrm{C}$ or below) at the time of the survey, was used to see how our data compared with previous analyses of the relationship between heavy episodic drinking and GPA. About $47 \%$ of respondents reported an $\mathrm{A}$ or 
TABLE 1.

Engagement Scales

\begin{tabular}{|c|c|c|}
\hline Scale & Alpha & Items \\
\hline $\begin{array}{l}\text { Student-Faculty } \\
\text { Interaction }\end{array}$ & .85 & $\begin{array}{l}\text { Discussed your career plans and ambitions with a faculty member } \\
\text { Discussed your academic work with a faculty member } \\
\text { Had intellectual discussions with a faculty member outside of class } \\
\text { Discussed your course selection plans with a faculty member } \\
\text { Interacted with a faculty member at a social event }\end{array}$ \\
\hline Academic Challenge & .75 & $\begin{array}{l}\text { Worked on a paper or project where you had to integrate ideas from various } \\
\text { sources } \\
\text { Prepared a major written report of } 20 \text { or more pages for a class } \\
\text { Conducted research using historical archives, surveys, field work, or other primary } \\
\text { sources on a project } \\
\text { Revised a paper or composition two or more times before you were satisfied with it } \\
\text { Worked harder than you thought you could to meet the instructor's standards or } \\
\text { expectations } \\
\text { Asked a librarian or staff member for help in finding information on some topic } \\
\text { Worked on a project that used a special collection of books, materials or papers } \\
\text { Found something interesting while browsing in the library }\end{array}$ \\
\hline Diversity Experiences & .71 & $\begin{array}{l}\text { American Indian or Alaska Native } \\
\text { Asian American } \\
\text { Native Hawaiian or Other Pacific Islander } \\
\text { Black or African American } \\
\text { Hispanic or Latino } \\
\text { From outside the U.S. } \\
\text { Different religion from yours } \\
\text { Different economic background from yours }\end{array}$ \\
\hline Enriching Experiences & .62 & $\begin{array}{l}\text { Attended a concert or other music event, on or off campus } \\
\text { Participated in a music activity (orchestra, chorus, etc.) on or off campus } \\
\text { Participated in art (pottery, painting, etc.) or theatrical production (acted, danced, etc.) } \\
\text { on or off campus } \\
\text { Read or discussed the opinions of art, music, or drama critics }\end{array}$ \\
\hline $\begin{array}{l}\text { Active and Collaborative } \\
\text { Learning }\end{array}$ & .54 & $\begin{array}{l}\text { Worked on a class assignment, project, or presentation with other students } \\
\text { Participated in class discussions } \\
\text { Made a formal presentation in class } \\
\text { Prepared for class with an informal study group } \\
\text { Discussed intellectual ideas with other students outside of class }\end{array}$ \\
\hline
\end{tabular}

Note. For student-faculty interaction, academic challenge, enriching experiences, and active and collaborative learning, the survey question was, "During this academic year, how often have you done each of the following?" The response scale for each item was never, occasionally, often, and very often. For diversity experiences, the survey question was, "Please indicate the extent to which you interacted with students from each of the following groups during this academic year." The response scale for each item was none, little, some, and substantial. 
A- average, and $35 \%$ reported a $\mathrm{B}+$ or $\mathrm{B}$ average.

The second set of dependent variables was a series of five engagement scales that measure student-faculty interaction, academic challenge, diversity experiences, enriching experiences, and active and collaborative learning. These scales are similar to those used by other scholars (e.g., Kuh \& Hu, 2001; Zhao, Kuh, \& Carini, 2005). The scales are summated rating scales that have been standardized with a mean of 0 and standard deviation of 1 to aid interpretation. Scale reliabilities and the survey items comprising each scale are listed in Table 1.

The third set of dependent variables was four time-use scales measuring how much time students spend on recreational, sports, extracurricular, and academic activities. As Astin (1993) has pointed out, alcohol use is negatively correlated with hours per week studying. The scales use a series of questions that ask students to indicate how much time they spend on a variety of activities during a typical week; responses could range from 0 hours to more than 30 hours per week. The scales are summated rating scales, standardized with a mean of 0 and standard deviation of 1 to aid interpretation. Scale reliabilities and the survey items comprising each scale are listed in Table 2.

\section{Independent Variables}

Our main independent variable of interest,

TABLE 2.

Time Use Scales

\begin{tabular}{|c|c|c|}
\hline Scale & Alpha & Items \\
\hline Recreational & .68 & $\begin{array}{l}\text { Socializing and talking with friends } \\
\text { Watching TV } \\
\text { Using a computer for non-academic activity (e.g., video games) } \\
\text { Using E-mail or Instant Messenger for recreation } \\
\text { Relaxing by yourself }\end{array}$ \\
\hline Sports & .64 & $\begin{array}{l}\text { Playing on intramural athletic team(s) } \\
\text { Competing informally on a team or sport (e.g., "pick-up" game) }\end{array}$ \\
\hline Extracurricular & .63 & $\begin{array}{l}\text { Participating in student government } \\
\text { Working on a campus newspaper } \\
\text { Working on a literary magazine } \\
\text { Volunteering in the community } \\
\text { Participating in a political organization } \\
\text { Participating in minority or ethnic organization } \\
\text { Participating in another organized student activity or club }\end{array}$ \\
\hline Academic & .56 & $\begin{array}{l}\text { Attending scheduled classes or labs } \\
\text { Working on scheduled courses outside of class or lab (i.e., homework) } \\
\text { Using a computer for academic work }\end{array}$ \\
\hline
\end{tabular}

Note. The survey question was, "During this academic year, approximately how many hours do you spend during a typical week doing the following activities?" The response scale for each item was none, less than 2 hours, 2 to 4 hours, 5 to 10 hours, 11 to 15 hours, 16 to 20 hours, 21 to 25 hours, 26 to 30 hours, more than 30 hours. 
TABLE 3.

Prevalence of Heavy Episodic Drinking by Gender and School Type

\begin{tabular}{|c|c|c|c|c|c|}
\hline \multirow[b]{2}{*}{ School Type } & \multirow{2}{*}{$\begin{array}{l}\text { Frequency of Heavy } \\
\text { Episodic Drinking }\end{array}$} & \multicolumn{2}{|c|}{$\%$} & \multicolumn{2}{|c|}{$n$} \\
\hline & & Females & Males & Females & Males \\
\hline Research Universities & None & 61 & 51 & 10,681 & 7,468 \\
\hline \multirow[t]{5}{*}{$(N=15)$} & 1 occasion & 16 & 15 & 2,812 & 2,267 \\
\hline & 2 occasions & 10 & 11 & 1,691 & 1,687 \\
\hline & 3 occasions & 6 & 8 & 1,074 & 1,152 \\
\hline & 4 or more occasions & 8 & 15 & 1,353 & 2,153 \\
\hline & Totals & 100 & 100 & 17,611 & 14,727 \\
\hline Coed Colleges & None & 55 & 44 & 1,686 & 1,039 \\
\hline \multirow[t]{5}{*}{$(N=8)$} & 1 occasion & 19 & 18 & 581 & 428 \\
\hline & 2 occasions & 11 & 14 & 339 & 320 \\
\hline & 3 occasions & 6 & 10 & 200 & 225 \\
\hline & 4 or more occasions & 9 & 15 & 272 & 356 \\
\hline & Totals & 100 & 100 & 3,078 & 2,368 \\
\hline Women's colleges & None & 70 & & 2,663 & \\
\hline \multirow[t]{5}{*}{$(N=5)$} & 1 occasion & 15 & & 589 & \\
\hline & 2 occasions & 8 & & 299 & \\
\hline & 3 occasions & 4 & & 142 & \\
\hline & 4 or more occasions & 3 & & 122 & \\
\hline & Totals & 100 & & 3,815 & \\
\hline
\end{tabular}

alcohol use, was measured with a question that has been standard in the college alcohol research field for several decades: "Thinking back over the last two weeks, on how many occasions, if any, have you had five or more alcoholic drinks?" Respondents could answer with “0," “ 1 ," “2," “ 3 ," or “4 or more occasions." Table 3 shows the distribution of this variable for females and males by school type. As can be seen, males are more likely than females to report 3 or 4 or more occasions of heavy drinking, whereas females at women's colleges are less likely to report heavy episodic drinking compared with females at research universities or coed colleges. Because the effect of alcohol use could be nonlinear, we used four dummy variables to measure heavy drinking, with each dummy variable indicating that the student had five or more drinks on 1, 2, 3 or 4 or more occasions, with no occasions of heavy drinking as the reference category.

The control variables used in all analyses are presented in Table 4. To control for differences in student background, we included self-reported combined SAT scores and five dummy variables indicating the student was Asian, Black, Hispanic, an international student, or race/ethnicity missing or unknown, with Whites as the reference category. We also included a dummy variable indicating that neither parent graduated from college. To control for differences in college experiences, we included dummy variables indicating that the student was on financial aid, a transfer 
student, class year, on-campus residence, member of a fraternity of sorority, participation in intercollegiate athletics, and academic major.

\section{Statistical Techniques}

Because GPA is an ordered interval scale, we used ordinal logistic regression to estimate the relationship between GPA and heavy episodic drinking. The resulting coefficients were not directly interpretable and we instead reported the discrete change in the probability of a student reporting a GPA of A or A- (the top two categories of the six-point scale) (Long, 1997). These probabilities were calculated using the sample means for the other independent variables. The engagement and time use scales are continuous variables, so we used multiple regression to analyze the impact of heavy episodic drinking.

TABLE 4.

Descriptive Statistics for Independent Variables

\begin{tabular}{|c|c|c|c|c|}
\hline \multirow[b]{2}{*}{ Variable } & \multicolumn{2}{|c|}{ Females } & \multicolumn{2}{|c|}{ Males } \\
\hline & Mean & $S D$ & Mean & $S D$ \\
\hline \multicolumn{5}{|l|}{ Demographics } \\
\hline SAT Score & 1388 & 117.4 & 1429 & 110.6 \\
\hline Asian & 0.17 & 0.38 & 0.16 & 0.36 \\
\hline Black & 0.06 & 0.24 & 0.04 & 0.20 \\
\hline Hispanic & 0.06 & 0.24 & 0.06 & 0.23 \\
\hline International Student & 0.05 & 0.23 & 0.07 & 0.25 \\
\hline Other/Unknown Race/Ethnicity & 0.01 & 0.12 & 0.02 & 0.13 \\
\hline First Generation Student & 0.16 & 0.36 & 0.14 & 0.35 \\
\hline \multicolumn{5}{|l|}{ College Experiences } \\
\hline Financial Aid Status & 0.51 & 0.50 & 0.47 & 0.50 \\
\hline Transfer Student & 0.05 & 0.21 & 0.04 & 0.20 \\
\hline Class Year: Second & 0.26 & 0.44 & 0.26 & 0.44 \\
\hline Class Year: Third & 0.22 & 0.42 & 0.23 & 0.42 \\
\hline Class Year: Fourth & 0.25 & 0.43 & 0.23 & 0.42 \\
\hline Resides On Campus & 0.81 & 0.39 & 0.81 & 0.39 \\
\hline Fraternity/Sorority Member & 0.19 & 0.39 & 0.24 & 0.43 \\
\hline Intercollegiate Athlete & 0.21 & 0.41 & 0.26 & 0.44 \\
\hline Major: Arts and Humanities & 0.25 & 0.43 & 0.18 & 0.38 \\
\hline Major: Social Sciences & 0.28 & 0.45 & 0.25 & 0.43 \\
\hline Major: Natural Sciences/Math & 0.17 & 0.38 & 0.22 & 0.41 \\
\hline Major: Other & 0.04 & 0.20 & 0.03 & 0.16 \\
\hline Major: Unknown & 0.07 & 0.26 & 0.06 & 0.23 \\
\hline
\end{tabular}


TABLE 5.

Summary of Ordinal Logistic Regression Results: Impact of Heavy Episodic Drinking on GPA

\begin{tabular}{|c|c|c|c|c|c|}
\hline \multirow{2}{*}{$\begin{array}{l}\text { Frequency of Heavy } \\
\text { Episodic Drinking }\end{array}$} & \multicolumn{2}{|c|}{$\begin{array}{l}\text { Research } \\
\text { Universities }\end{array}$} & \multicolumn{2}{|c|}{$\begin{array}{l}\text { Coed } \\
\text { Colleges }\end{array}$} & \multirow{2}{*}{$\begin{array}{l}\text { Women's } \\
\text { Colleges }\end{array}$} \\
\hline & Females & Males & Females & Males & \\
\hline 1 occasion & $-0.05^{* *}$ & $-0.03 * *$ & -0.04 & -0.03 & $-0.07 * *$ \\
\hline 2 occasions & $-0.07 * *$ & $-0.07 * *$ & $-0.08 * *$ & -0.01 & $-0.11 * *$ \\
\hline 3 occasions & $-0.10 * *$ & $-0.07 * *$ & $-0.10 *$ & $-0.10 * *$ & $-0.14 * *$ \\
\hline 4 or more occasions & $-0.11 * *$ & $-0.10 * *$ & $-0.16 * *$ & $-0.12 * *$ & $-0.14 *$ \\
\hline
\end{tabular}

Note. Cell entries are percentage point changes in probability of having a GPA of A or A-.

$* p<.05 . \quad * * p<.01$.

One issue with the data used in this paper is its clustered nature. The data were not a simple random sample; instead, they were a clustered sample and had to be analyzed using statistical techniques that take into account this clustering (Groves et al., 2004). If not, then the estimated standard errors would most likely be too small. The standard errors for the ordinal logistic and multiple regression results presented here are adjusted for this clustering.

\section{LIMITATIONS}

As with any research, there are limitations to our analysis. First, the biggest limitation to our analysis is the sample. The sample was not a random sample of college students across the nation but was instead a random sample of students from highly selective, private institutions. As such, we should be cautious in generalizing our results to all college students.

Second, some of our scales have low reliabilities, such as the Active and Collaborative Learning scale (alpha $=.54)$ and Academic Time Use scale (alpha $=.56)$. This is the result of using an instrument designed and administered by other researchers for purposes other than our research project. Clearly, thorough pretesting of survey instruments and scales would allow future researchers to design similar scales with higher reliabilities.

Third, one could argue that engagement affects alcohol use and not the other way around. That is, students who are less engaged turn to heavy alcohol use, which in turn would explain some of the relationships we find. We have not discovered any research that makes this argument; future research could adopt a simultaneous equations approach to test this argument.

\section{RESULTS}

Consistent with previous research, we found that heavy episodic drinking ranged from a low of $30 \%$ at the women's colleges to a high of $56 \%$ among males at coed colleges. Women were less likely to be heavy episodic drinkers, as were students attending research universities.

The impact of heavy episodic drinking on GPA is shown in Table 5. The entries in this table are the percentage point change in the probability of reporting an A average for a given level of reported drinking; the reference group is no reported heavy drinking. The results indicate that students who reported 
drinking heavily tended to have lower GPAs; for example, the probability of a student reporting an A average was 10 to 16 percentage points lower for students who drink heavily four or more times in a 2 -week period than for students who do not drink at all. This is consistent with previous research findings that students engaged in heavy episodic drinking were less likely to have a GPA of A or A-. The probability of a GPA of A or A- decreases as episodes of heavy episodic drinking per 2-week period increase.

Table 6 summarizes the results from the engagement regressions, showing the impact of heavy drinking on various types of engagement. Because the dependent variables were

TABLE 6.

Summary of Regression Results: Impact of Heavy Episodic Drinking on Engagement

\begin{tabular}{|c|c|c|c|c|c|c|}
\hline \multirow[b]{2}{*}{ Areas of Engagement } & \multirow{2}{*}{$\begin{array}{l}\text { Frequency of Heavy } \\
\text { Episodic Drinking }\end{array}$} & \multicolumn{2}{|c|}{$\begin{array}{c}\text { Research } \\
\text { Universities } \\
\end{array}$} & \multicolumn{2}{|c|}{$\begin{array}{c}\text { Coed } \\
\text { Colleges } \\
\end{array}$} & \multirow{2}{*}{$\begin{array}{l}\text { Women's } \\
\text { Colleges }\end{array}$} \\
\hline & & Females & Males & Females & Males & \\
\hline \multirow[t]{4}{*}{ Student-Faculty Interaction } & 1 occasion & $-0.06 *$ & $-0.06 * *$ & -0.07 & -0.04 & -0.03 \\
\hline & 2 occasions & $-0.06^{+}$ & $-0.08^{*}$ & -0.11 & -0.06 & -0.09 \\
\hline & 3 occasions & $-0.15^{* *}$ & $-0.12 * *$ & -0.12 & -0.07 & -0.18 \\
\hline & 4 or more occasions & $-0.17 * *$ & $-0.16 * *$ & -0.03 & $-0.22 *$ & 0.08 \\
\hline \multirow[t]{4}{*}{ Academic Challenge } & 1 occasion & $-0.04 *$ & -0.04 & $-0.07^{*}$ & -0.04 & 0.09 \\
\hline & 2 occasions & -0.01 & -0.01 & -0.03 & -0.05 & 0.00 \\
\hline & 3 occasions & $-0.07^{+}$ & -0.04 & $-0.11 *$ & -0.01 & 0.00 \\
\hline & 4 or more occasions & $-0.08 * *$ & $-0.11 *$ & -0.01 & -0.06 & 0.30 \\
\hline \multirow[t]{4}{*}{ Diversity Experiences } & 1 occasion & $0.03^{+}$ & 0.03 & $-0.18^{*}$ & -0.02 & 0.01 \\
\hline & 2 occasions & 0.00 & 0.00 & -0.07 & -0.03 & 0.00 \\
\hline & 3 occasions & 0.00 & 0.01 & -0.23 & 0.01 & 0.16 \\
\hline & 4 or more occasions & $-0.11 *$ & $-0.08^{*}$ & -0.14 & -0.02 & 0.23 \\
\hline \multirow[t]{4}{*}{ Enriching Experiences } & 1 occasion & $-0.04^{+}$ & $0.05^{*}$ & -0.06 & -0.01 & 0.03 \\
\hline & 2 occasions & -0.07 & 0.04 & $-0.11 *$ & -0.06 & -0.01 \\
\hline & 3 occasions & $-0.10 * *$ & $0.07 *$ & $-0.17^{*}$ & -0.03 & 0.02 \\
\hline & 4 or more occasions & $-0.16 * *$ & 0.00 & $-0.07 *$ & -0.04 & 0.14 \\
\hline \multirow{4}{*}{$\begin{array}{l}\text { Active and Collaborative } \\
\text { Learning }\end{array}$} & 1 occasion & 0.01 & 0.00 & -0.01 & -0.04 & 0.05 \\
\hline & 2 occasions & -0.02 & 0.01 & 0.03 & -0.06 & 0.02 \\
\hline & 3 occasions & -0.04 & -0.03 & $-0.15^{+}$ & 0.00 & -0.07 \\
\hline & 4 or more occasions & $-0.08 *$ & -0.06 & 0.06 & $-0.15^{*}$ & 0.13 \\
\hline
\end{tabular}

Note. Cell entries are regression coefficients.

${ }^{+} p<.10 . \quad * p<.05 . \quad * * p<.01$. 
TABLE 7.

Summary of Regression Results: Impact of Heavy Episodic Drinking on Time Use

\begin{tabular}{|c|c|c|c|c|c|c|}
\hline \multirow[b]{2}{*}{ Time Spent On... } & \multirow{2}{*}{$\begin{array}{l}\text { Frequency of Heavy } \\
\text { Episodic Drinking }\end{array}$} & \multicolumn{2}{|c|}{$\begin{array}{l}\text { Research } \\
\text { Universities }\end{array}$} & \multicolumn{2}{|c|}{$\begin{array}{l}\text { Coed } \\
\text { Colleges }\end{array}$} & \multirow{2}{*}{$\begin{array}{l}\text { Women's } \\
\text { Colleges }\end{array}$} \\
\hline & & Females & Males & Females & Males & \\
\hline \multirow[t]{4}{*}{ Academics } & 1 occasion & $-0.12 * *$ & $-0.17 * *$ & -0.04 & -0.02 & $-0.13 * *$ \\
\hline & 2 occasions & $-0.16 * *$ & $-0.25^{* *}$ & $-0.16^{+}$ & $-0.16 *$ & -0.14 \\
\hline & 3 occasions & $-0.24 * *$ & $-0.27 * *$ & $-0.13^{+}$ & $-0.13^{+}$ & -0.23 \\
\hline & 4 or more occasions & $-0.32 * *$ & $-0.39 * *$ & $-0.20 *$ & $-0.30 * *$ & -0.17 \\
\hline \multirow[t]{4}{*}{ Extracurriculars } & 1 occasion & 0.00 & 0.00 & -0.02 & 0.05 & $0.10^{+}$ \\
\hline & 2 occasions & 0.00 & 0.03 & -0.03 & -0.03 & -0.04 \\
\hline & 3 occasions & -0.04 & -0.07 & -0.07 & -0.01 & 0.06 \\
\hline & 4 or more occasions & $-0.08^{*}$ & $-0.07^{+}$ & -0.06 & $-0.21 * *$ & 0.05 \\
\hline \multirow[t]{4}{*}{ Recreation } & 1 occasion & $0.19 * *$ & $0.15^{* *}$ & $0.14 *$ & 0.02 & $0.31 * *$ \\
\hline & 2 occasions & $0.34 * *$ & $0.24 * *$ & $0.25 * *$ & $0.19^{+}$ & $0.29 * *$ \\
\hline & 3 occasions & $0.37 * *$ & $0.30 * *$ & $0.43 * *$ & $0.27 * *$ & 0.29 \\
\hline & 4 or more occasions & $0.62 * *$ & $0.62 * *$ & $0.59 * *$ & $0.49 * *$ & $0.59 *$ \\
\hline \multirow[t]{4}{*}{ Sports } & 1 occasion & $0.06 *$ & $0.14^{* *}$ & -0.01 & $0.13^{+}$ & 0.08 \\
\hline & 2 occasions & $0.07 * *$ & $0.23 * *$ & $0.09^{+}$ & $0.28 * *$ & 0.08 \\
\hline & 3 occasions & $0.08 * *$ & $0.32 * *$ & 0.11 & $0.47 * *$ & 0.07 \\
\hline & 4 or more occasions & $0.12 * *$ & $0.36 * *$ & 0.22 & $0.50 * *$ & 0.40 \\
\hline
\end{tabular}

Note. Cell entries are regression coefficients.

${ }^{+} p<.10 . \quad * p<.05 . \quad * * p<.01$.

standardized, the coefficients can be interpreted as the impact of drinking on a standard deviation of engagement. For example, looking at females in research universities, females who drink heavily four or more times in a 2-week period were engaged about .17 standard deviations less than females who do not drink heavily.

The strongest effects of heavy episodic drinking tended to be on student-faculty interaction, whereas the weakest effects were on active and collaborative learning and diversity experiences. The effects also appear to be most common at research universities, less common at coed colleges, and not statistically significant for women's colleges. Although the effects appear fairly similar for females and males at research universities, interestingly, the negative effects of heavy episodic drinking at coed colleges were more common for females than males. None of the engagement results for students at the women's colleges were statistically significant.

The largest negative effects on studentfaculty interaction occured at the heavy episodic rate of three and four times in a 2 -week period for both men and women at research universities. In order to impact 
engagement in academic challenge, students at research universities needed to be drinking at the 4-or-more-times-a-week level. Similarly, diversity experiences were lower for research university students drinking at this same level. There was a negative impact on the enriching experiences of women at both research universities and coed colleges at the higher levels of heavy episodic alcohol use, whereas the men in research universities showed a slightly positive impact in two of the four levels. Finally, active and collaborative learning showed an impact of heavy episodic drinking only at the $4+$ level for women at the research universities and men at the coed colleges.

The effect sizes for the time use regressions were much stronger than in the engagement regressions (see Table 7). Females at research universities who drink heavily four or more times in a 2 -week period, for example, spent time on academics about one third of a standard deviation less than females who reported no occasions of heavy drinking. There were significant negative effects at all levels of heavy episodic drinking for both sexes at the research universities, whereas the impact at the coed colleges was not observed until students have been drinking at this level four times in a 2 -week period. The only statistically significant impact at the women's colleges was at the one occasion level. With regard to time spent in recreation, there were relatively strong influences of heavy episodic drinking at all levels of frequency, although in these cases the effect was positive rather than negative. The pattern was similar for sports for men at both research universities and coed colleges, but for women only at research universities.

\section{DISCUSSION}

Our findings indicate that heavy drinking does matter. In each group we examined, students who engaged in heavy drinking had lower
GPAs. Furthermore, the more often one drank at the heavy episodic level the more likely it was that grades were lower. This finding replicates similar results in the literature, although this is the first such verification of the phenomenon in such a large database of highly selective institutions.

We also confirmed the finding in the literature that there are differential heavy episodic drinking levels by institution type: more students drank more heavily at the coed colleges than at the research universities, women to a lesser extent than the men, and women at women's colleges were the least likely to drink heavily.

We did find a differential relationship between heavy episodic drinking and student engagement by institution type. One of the most powerful predictors of positive educational outcomes is the level of student-faculty interaction, and students who are engaged with faculty in college are among those with the highest levels of achievement and satisfaction. Although students at research universities who were heavy episodic drinkers were less likely to be engaged in interactions with faculty than students who do not drink at this level, students at the coed colleges and women's colleges showed no such impact (with the exception of the males drinking at the highest level of frequency). What is it about these types of institutions that could explain such differences? One difference is that the coed and women's colleges have higher average levels of faculty-student engagement than the research universities. It might be the case that the higher level of engagement at these institutions helps students remain engaged despite their alcohol use, acting as a protective factor. At research universities, where the level of engagement is lower, perhaps the faculty and student relationship cannot withstand the adverse effects of frequent heavy episodic alcohol use. Colleges, generally, have more 
opportunities for faculty and students to develop relationships that can carry on despite occasional negative effects of heavy episodic alcohol use. Student affairs practitioners at research universities should be aware of the possible negative impact that heavy episodic alcohol use has on engagement.

The impact of heavy episodic alcohol use on engagement in other areas was not as profound. The most consistent finding was that heavy episodic drinking four or more times in 2 weeks by women at research universities negatively impacted each type of engagement we examined. Women at these institutions who drank less than this did not have, for the most part, reductions in other areas of engagement. Although men at research universities had similar patterns for academic challenge and in diversity experiences, even those drinking at the highest frequency did not see an impact on enriching experiences or active and collaborative learning.

Unlike engagement, the relationship between heavy episodic drinking and how students spend their time did not vary as much by institution type. There was also a strong negative relationship between heavy episodic alcohol use and the time students spend on academics. This was most common, again, at research universities but occurred at the coed colleges and the women's colleges to a lesser extent. At the research universities there was a clear negative association between the frequency of drinking at the heavy episodic level and the time students spend on academics. The more one drinks, the less time is spent on academics. In addition, the more one drinks the more one spends time on recreation and sports.

In this study we have seen that heavy episodic alcohol use impacts engagement, that students who drink at this level are less likely to have high GPAs, and that they are more likely to spend more time on recreation and athletics and less time on academics. The impact of heavy episodic alcohol use also differs by institution type and is most profound at research universities.

This secondary analysis of data collected for another purpose demonstrates that there is a significant impact on engagement with faculty that comes with episodic drinking. Because such interactions between faculty and students can be some of the most powerful and beneficial aspects of the college experience, further research that is more finely crafted to examine this issue is warranted.

Future research is needed in several different areas. First, the sample used here consisted of selective institutions; little is known about the effect of alcohol use on engagement at other types of institutions. Given our finding that the effect of heavy episodic alcohol use varies by institution type, research is needed to understand exactly what institutional characteristics may affect this relationship. Is it simply a function of size? Institutional culture? Or perhaps some other attribute of these institutions?

Another area of research that should be particularly useful, albeit difficult to conduct, is research that takes into account the potential endogeneity between alcohol use and other student behaviors. Most studies in this area (including this one) ignore the possibility that student outcomes, such as academic performance or engagement, may be affecting alcohol use, as well as alcohol use affecting student outcomes. Although some researchers have made strides in this area (e.g., Williams, Powell, \& Wechsler, 2003), other approaches using techniques such as propensity scores are sorely needed.

Correspondence concerning this article should be addressed to Stephen R. Porter, Department of Educational Leadership and Policy Studies, Lagomarcino Hall, Iowa State University, Ames, IA 50011; srporter@ iastate.edu 


\section{REFERENCES}

Anderson, D. S. \& Gadaleto, A. F. (2001). Results of the 2000 College Alcohol Survey: Comparison with 1997 results and baseline year. Retrieved May 23, 2005, from www.caph.gmu. edu/CAS/cas2000.pdf

Astin, A.W. (1984). Student involvement: A developmental theory for higher education. Journal of College Student Personnel, 25(4), 297-308.

Astin, A. W. (1993). What matters in college? San Francisco: Jossey-Bass

Bachman, J. G., Wadsworth, K. N., O’Malley, P. M., Johnston, L. D., \& Schulenberg, J. E. (1997). Smoking, drinking, and drug use in young adulthood: The impacts of new freedoms and new responsibilities. Mahwah, NJ: Lawrence Erlbaum Associates.

The Carnegie Foundation for the Advancement of Teaching. (1990). Campus life: In search of community. San Francisco: Jossey-Bass.

Groves, R. M., Fowler, F. L., Couper, M. P., Lepkowski, J. M., Singer, E., \& Tourangeau, R. (2004). Survey methodology. Hoboken, NJ: Wiley-Interscience.

Hingson, R., Heeren, T., Winter, M., \& Wechsler, H. (2005). Magnitude of alcohol-related mortality and morbidity among U.S. college students ages 18-24: Changes from 1998 to 2001. Annual. Review of Public Health, 26, 259-279.

Hingson, R. W., Heeren, T., Zakos, R. C., Kopstein, A., \& Wechsler, H. (2002). Magnitude of alcohol-related mortality and morbidity among U.S. college students ages 18-24. Journal of Studies on Alcohol, 63(2), 136-144.

Hu, S., \& Kuh, G. D. (2002). Being (dis)engaged in educationally purposeful activities: The influences of student and institutional characteristics. Research in Higher Education, 43(5), 555-575.

Kuh, G. D., Douglas, K. B., Lund, J. P., \& Ramin-Gyurnek, J. (1994). Student learning outside the classroom: Transcending artificial boundaries (ASHE-ERIC Higher Education Report No. 8). Washington, DC: The George Washington University, Graduate School of Education and Human Development.

Kuh, G. D., \& Hu, S. (2001). The effects of student-faculty interaction in the 1990s. Review of Higher Education, 24(3), 309-332.

Kuh, G. D., Schuh, J., Whitt, E. \& Associates. (1991). Involving colleges: Successful approaches to fostering student learning and development outside the classroom. San Francisco: Jossey-Bass.

Long, J. S. (1997). Regression models for categorical and limited dependent variables. Thousand Oaks, CA: Sage.
National Institute on Alcohol Abuse and Alcoholism. (2002). A call to action: Changing the culture of drinking at U.S. colleges (NIH Pub. No. 02-5010). Bethesda, MD: Author.

Pascarella, E. \& Terenzini, P. (1991). How college affects students: Findings and insights from twenty years of research. San Francisco: Jossey-Bass.

Pascarella, E. \& Terenzini, P. (2005). How college affects students: $A$ third decade of research. San Francisco: Jossey-Bass.

Pike, G. R., \& Askew, J. W. (1990). The impact of fraternity or sorority membership on academic involvement or learning outcomes. NASPA Journal, 28, 13-19.

Powell, L. M., Williams, J., \& Wechsler, H. (2004). Study habits and the level of alcohol use among college students. Education Economics, 12(2), 135-149.

Presley, C. A. Meilman, P. W., \& Cashin, J. R. (1996); Alcohol and drugs on American college campuses: Use, consequences, and perceptions of the campus environment: Vol. IV. 1992-94. Carbondale, IL: Core Institute, Southern Illinois University.

Umbach, P. D., \& Wawrzynski, M. R. (2004). Faculty do matter: The role of college faculty in student learning and engagement. Paper presented at the 2004 Annual Meeting of the Association for Institutional Research, Boston, MA.

Wechsler, H., Lee, J. E., Kuo, M., Seibring, M., Nelson, T., \& Lee, H. (2002). Trends in college binge drinking during a period of increased prevention efforts. Journal of American College Health, 50, 203-217.

Wechsler, H., \& Nelson, T. (2001). Binge drinking and the American college student: What's five drinks? Psychology of Addictive Behaviors, 15, 287-291.

Weitzman, E. R., Nelson, T. F., \& Wechsler, H. (2003). Taking up binge drinking in college: The influences of person, social group, and environment. Journal of Adolescent Health, 32, 26-35.

White, A. M., Jamieson-Drake, D., \& Swartzwelder, H. S. (2002). Prevalence and correlates of alcohol-induced blackouts among college students: Results of an email survey. Journal of American College Student Health, 51, 117-131.

Williams, J., Powell, L. M., \& Wechsler, H. (2003). Does alcohol consumption reduce human capital accumulation? Evidence from the College Alcohol Study. Applied Economics, 35, 1227-1239.

Zhao, C. M., Kuh, G. D., \& Carini, R. M. (2005). A comparison of international student and American student engagement in effective educational practices. Journal of Higher Education, 76(2), 209-231. 